\title{
Changes in the hypothalamic-hypophyseal axis of mares in relation to the winter solstice
}

\author{
P. J. Silvia ${ }^{1}$, L. Johnson ${ }^{2}$ and B. P. Fitzgerald ${ }^{1}$ \\ ${ }^{1}$ University of Kentucky, Department of Veterinary Science, 108 Gluck Equine Research Center, \\ Lexington, KY 40546-0099, USA; and ${ }^{2}$ Texas $A$ and M University, Department of Veterinary \\ Anatomy, College Station, TX 77843, USA
}

\begin{abstract}
Summary. In mares, the amount of gonadotrophin-releasing hormone (GnRH) is low in the hypothalamus during seasonal anoestrus, but by early spring, concentrations of GnRH are high. The timing of this response was characterized more precisely by determining concentrations of GnRH in hypothalamic tissue collected immediately before and at various times after the winter solstice (22 December 1986). Ovaries, pituitary gland, hypothalamus and a blood sample were collected from six groups of mares (6-12 mares per group) at death, 1 week before day of the winter solstice and 1,2, 3 and 12 weeks afterwards. No significant changes in weight of the anterior pituitary gland or concentrations of luteinizing hormone $(\mathrm{LH})$ and follicle-stimulating hormone (FSH) were observed in the anterior pituitary gland $(P>0 \cdot 1)$. Mean diameter of the largest follicle, number of follicles $\geq 20 \mathrm{~mm}$ in diameter and concentrations of LH and FSH in serum remained unchanged for weeks -1 to $+3(P>0.05)$, then increased significantly by week $12(P<0.001)$. Content and concentration of GnRH in the median eminence was low at -1 week, increased gradually $(P<0.05)$ to a maximum by +1 week, then decreased gradually $(P<0.05)$ to low values at 12 weeks. Means $( \pm$ SEM) for $-1,+1$ and +12 weeks were $33 \cdot 5 \pm 5 \cdot 5,117 \cdot 7 \pm 18.6$ and $29.8 \pm 3.7 \mathrm{ng} \mathrm{GnRH}$, respectively. Mean content of GnRH in the preoptic area of the hypothalamus showed a reciprocal pattern. Since content of GnRH in the median eminence was increasing on the day of the winter solstice, the impetus for resurgence of GnRH synthesis may not be lengthening photoperiod, but refractoriness to the previous short photoperiod. Increased gonadotrophin content observed at 12 weeks suggests that the coincidental reduction in content of GnRH may be due to an increase in secretion. One role of lengthening photoperiod may therefore be to boost production of $\mathrm{GnRH}$ during a period of increasing release.
\end{abstract}

Keyw'ords: mare; LH; GnRH; hypothalamus; pituitary; photoperiod

\section{Introduction}

In mares, a period of transition from reproductive quiescence (anoestrus) to cyclical activity (breeding season) occurs annually in association with increasing daylength (Arthur, 1958; Osborne, 1966). Daylength appears to induce these changes, with long days stimulating the attainment of reproductive competence (Burkhardt, 1947; Loy, 1968; Kooistra \& Ginther, 1975; Palmer et al., 1982) and short days inhibiting this development (Loy, 1968; Kooistra \& Ginther, 1975). During anoestrus, follicular development is minimal and signs of oestrous behaviour are absent or sporadic (Ginther, 1979). Hypothalamic and pituitary function appear to be depressed near the time of the winter solstice. Mean concentrations of luteinizing hormone (LH) (Garcia \& Ginther, 1976; Oxender et al., 1977; Freedman et al., 1979) and follicle-stimulating hormone (FSH) (Silvia et al., 
1987) in serum are low, reflecting an infrequent pattern of episodic release (Fitzgerald et al., 1987; Fitzgerald \& Mellbye, 1988; Hines et al., 1991). Concentrations of LH extracted from pituitary tissue are significantly low at this time (Hart et al., 1984; Silvia et al., 1986), but pituitary concentrations of FSH are not reduced in tissue collected during anoestrus. Hart et al. (1984) reported a significant reduction in hypothalamic content of gonadotrophin-releasing hormone (GnRH) during anoestrus (tissue collected on 22 December). Secretion of GnRH, as measured by pushpull perfusion of the medial basal hypothalamus, was also significantly lower in perfusate from anoestrous mares (Sharp \& Grubaugh, 1987).

As daylength increases gradually, and mares begin the transition into the breeding season, basal concentrations of LH and FSH as well as pituitary concentrations of LH increase gradually (Silvia et al., 1986; Silvia et al., 1987). However, early in this transition period (15 March), content of GnRH in hypothalamic tissue has already risen markedly, to values that are not different from those observed during the breeding season, while pituitary LH still remains depressed (Hart et al., 1984). On the basis of these observations, the seasonal restoration of reproductive endocrine function in mares appears to occur more rapidly at the hypothalamic level than at the pituitary or ovarian level. In a subsequent study, the GnRH content of hypothalamic tissue collected from anoestrous mares (tissue collected on 9 January) was not reduced (Silvia et al., 1986). These authors proposed that GnRH content may have been high in these anoestrous mares as a result of their brief exposure to an increasing photoperiod between 22 December and 9 January. Alternatively, high concentrations of $\mathrm{GnRH}$ could have resulted from decreased responsiveness of the hypothalamopituitary unit to the inhibitory effects of short daylengths (i.e. photorefractoriness).

This experiment was designed to characterize further the changes in hypothalamic content of GnRH that occur after the winter solstice.

\section{Materials and Methods}

\section{Animals and tissue collection}

Ovaries, pituitary gland, hypothalamus and a blood sample were collected from nonpregnant horse mares between 2.5 and 18 years of age, at a slaughterhouse in Fort Worth, Texas, USA (Bell-Tech Co.). Tissue was collected 1 week before (group -1 ), on the day of (group 0 ), and $1,2,3$ and 12 weeks (groups $+1,+2,+3$ and +12 , respectively) after the winter solstice (22 December 1986). Group +12 was included to provide endpoint values representative of the early transition phase for comparison. Mares were selected at the time of tissue collection according to (i) no luteal structures and (ii) diameter of the largest follicle $\leqslant 25 \mathrm{~mm}$ (group +12 excluded). The ovaries were cleaned free of connective tissue and weighed; they were then sectioned and the number and size of follicular structures were recorded. Pituitary and hypothalamic tissue were immediately wrapped in foil and frozen in liquid nitrogen. Mares with $>\mathrm{l} \mathrm{ng} \mathrm{progesterone} \mathrm{ml}^{-1}$ in serum were excluded from the experiment. The final number of mares in each group was $8,11,6,9,10$, and 12 for groups $-1,0,+1,+2,+3$ and +12 , respectively.

\section{Pituitary tissue and serum}

The posterior pituitary was removed and an anterior pituitary homogenate prepared as previously described (Hart et al., 1984). Concentrations of LH (Silvia \& Fitzgerald, 1991) and FSH (Hines et al., 1987) in serum and supernatant from the anterior pituitary homogenate were determined by heterologous radioimmunoassay. Experimental serum samples were run in single assays for both LH and FSH, the intra-assay coefficients of variation were $7.2 \%$ and $6.0 \%$, respectively. FSH content of pituitary samples was also determined in the assay previously mentioned. Measurement of $\mathrm{LH}$ in pituitary samples was performed in two assays. Intra- and interassay coefficients of variation of these assays were $8.0 \%$ and $19.2 \%$, respectively. Concentrations of progesterone in serum were determined using a diagnostic kit (Serono Diagnostics, Inc., Norwell, Massachusetts, USA) modified for equine samples. Intra-assay variation of the single assay was $5 \cdot 6 \%$. Sensitivity of this assay ( $90 \%$ of the specific counts bound) was equal to $0.11 \mathrm{ng}$ progesterone $\mathrm{ml}^{-1}$.

\section{Hypothalamic tissue}

Hypothalamic tissue was thawed and the median eminence region removed. Before homogenization, the pituitary gland was inspected for remnants of median eminence tissue. If present, this tissue was removed and combined with that obtained from the hypothalamus. The remaining block of hypothalamic tissue was then dissected into two areas, 
according to the method of Moss et al. (1980): (i) the anterior hypothalamic/preoptic-suprachiasmatic area and (ii) the body of the hypothalamus. Each region was weighed then extracted with methanol-formic acid (Hart et al., 1984) for subsequent measurement of $\mathrm{GnRH}$ content by radioimmunoassay. A double-antibody radioimmunoassay using an equine anti-GnRH generated in our laboratory was used to measure GnRH in extracts from hypothalamic tissue. The anti-GnRH antiserum was prepared by injection of horse mares with $\mathrm{GnRH}$ that had been conjugated to human serum albumin (Safir et al., 1987). Serum from mare 77 (M77) showed the best anti-GnRH titre after several immunizations and was selected for use in the radioimmunoassay. ${ }^{125}$ I-labelled GnRH (Wyeth AY-24031-A-29: Wyeth Laboratories, Philadelphia) was prepared by the glucose oxidase-lactoperoxidase iodination method (Tower et al., 1980). Purification of the reaction mixture was achieved using a QAE-Sephadex anion exchange column eluted with a Tris-bovine serum albumin (BSA) buffer $\left(0.005 \mathrm{~mol}\right.$ Trizma-HCl $1^{-1}, 0 \cdot 1 \% \mathrm{BSA}$; $\left.\mathrm{pH} 9 \cdot 2\right)$. M77 anti-GnRH was initially diluted $1: 200$ with assay buffer $\left(0.01 \mathrm{~mol} \mathrm{PBS}^{-1}, 0.2 \% \mathrm{BSA} ; \mathrm{pH} 7.4\right)$; subsequent dilutions needed to obtain the working titre were made using 1:200 normal horse serum. Fifty microlitres of $\mathrm{M} 77$ (initial working dilution $=1: 2000$ ) was added to $400 \mu \mathrm{l}$ of assay buffer and sample or standard. The same GnRH preparation used for iodination was also used as reference standard. After a $24 \mathrm{~h}$ incubation at $4^{\circ} \mathrm{C}, 50 \mu \mathrm{l}$ of ${ }^{125} \mathrm{I}$-labelled $\mathrm{GnRH}$ was added. After incubation for $24 \mathrm{~h}$ at $4^{\circ} \mathrm{C}, 200 \mu \mathrm{l}$ (initial dilution $=1: 12$ ) of rabbit anti-horse gamma globulin (Cappel Laboratories, West Chester, Pennsylvania) was added to precipitate the antigen-antibody complexes. The resulting mixture was incubated for a further $24 \mathrm{~h}$ at $4^{\circ} \mathrm{C}$, after which $3 \mathrm{ml}$ cold PBS was added followed by centrifugation for $30 \mathrm{~min}$ at $1643 \mathrm{~g}$. After decanting the supernatant, radioactivity of the pelleted precipitate was measured in a gamma counter.

Sensitivity of this assay ( $90 \%$ of specific counts bound; $n=8$ ) averaged $3 \cdot 7 \pm 1 \cdot 1$ pg per tube (mean \pm SEM). Nonspecific binding ranged from 1 to $4 \%$ of the total radioactivity added. Specific binding ranged from 13 to $30 \%$ of the total amount of radioactivity. When observed values for the recovery of known amounts of GnRH standard (15, $50,250,1000 \mathrm{pg}$ ), added to two different hypothalamic extracts, were plotted versus expected values a straight line $\left(r^{2}=0.99\right)$ with slope of 0.97 and intercept of zero $(P>0.1)$ was obtained. Log-logit plot of the dose-response curve for the GnRH standard and eight hypothalamic extracts produced lines with comparable slopes $(P>0 \cdot 1)$. M77 crossreacted $\leqslant 2 \%$ with [Gly-OH $\left.{ }^{10}\right]$-GnRH, des-Gly ${ }^{10}-$ GnRH-NHEt, [D-Ala $]-G n R H$, des-Gly ${ }^{10},\left[D T r p^{6}, N-M e-\right.$ Leu $^{7}$ ]-GnRH-NHEt, des-Gly ${ }^{10},\left[D-T_{1}{ }^{6}\right]-G n R H-N H E t,\left[D-P h e^{2,6}\right.$, Pro $^{3}$ ]-GnRH, oxytocin, vasopressin, somatostatin and thyrotrophin-releasing hormone. $763 \%$ crossreactivity of $\mathrm{GnRH}$ with des-p Glu ${ }^{1}$-GnRH was observed with $\mathrm{M} 77$.

Hypothalamic samples (of which all samples from this study were a subset) were run in duplicate using each assay system to compare the M77-GnRH assay system with an established assay for GnRH (Nett \& Adams, 1977; antiserum = rabbit (42) anti-GnRH). The assays were conducted on the same day using the same [ $\left.{ }^{125} \mathrm{I}\right]-\mathrm{GnRH}$ preparation. Least squares regression analysis of the resulting $\mathrm{GnRH}$ estimates produced a linear equation with a slope of 0.90 and intercept of 0.22 . The coefficient of determination $\left(r^{2}\right)$ for this line was 0.91 . Analysis by paired $t$ test supported the null hypothesis that the difference between paired values was equal to zero $(P>0 \cdot 1)$.

\section{Statistical analysis}

Changes in the frequency distribution of the number of follicles $\geq 20 \mathrm{~mm}$ in diameter, over time relative to the winter solstice, were tested by $\chi$-square analysis. Effects of time on all other parameters were evaluated by analysis of variance for unequal sample sizes (SAS, 1985). Data with significant heterogeneity of variance were transformed to the natural logarithm before analysis. When the overall effect of time was significant, group means were compared by Tukey's HSD, at alpha $=0.05$ and 0.01 where appropriate. In addition, significance of the orthogonal contrast of groups $-1,0,+1,+2$ and +3 versus group +12 was tested.

\section{Results}

The estimated age of mares at the time of tissue collection was not different between groups $(P>0.05)$ (overall mean \pm SEM: $10.48 \pm 0.74$ years). On the basis of the observation that there was no luteal tissue in the ovaries and that concentrations of progesterone were $<1 \mathrm{ng} \mathrm{ml}^{-1}$ (Hughes et al., 1972), all mares used in this experiment were considered seasonally anovulatory. The mean ( \pm SEM) concentration of progesterone in serum for all mares was $0 \cdot 117 \pm 0.019 \mathrm{ng} \mathrm{ml}^{-1}$ (Table 1). Ovarian activity, reflected by the parameters shown in Table 1, did not change over the 4 weeks spanned by groups -1 to $+3(P>0 \cdot 1)$. Mares in these groups were considered to be in deep anoestrus (Silvia et al., 1986). There was a significant increase in both the number of follicles $\geq 20 \mathrm{~mm}$ in diameter and diameter of the largest follicle by the 12th week after the winter solstice $(P<0.01)$. Although there was no overall effect of group on paired ovarian weight, when the sums of squares were partitioned for the orthogonal contrast of groups $-1,0,+1,+2$ and +3 versus group +12 a significant increase was observed $(P<0.01)$. Both LH and FSH concentrations remained relatively low and did not change over the initial 4 weeks (Fig. 1) and then increased 
significantly by week $+12(P<0.05)$. The large standard error associated with the mean gonadotrophin concentration for group +1 reflects extremely high values observed in one individual, possibly due to an episodic release of those hormones.

Table 1. Mean ( \pm SEM) indicators of ovarian activity in mares and the approximate length of day in Fort Worth, Texas $\left(32^{\circ} 45 \cdot 0^{\prime} \mathrm{N}, 97^{\circ} 17 \cdot 7^{\prime} \mathrm{W}\right)$ at various times of tissue collection

\begin{tabular}{|c|c|c|c|c|c|}
\hline \multirow[b]{2}{*}{ Group } & \multirow[b]{2}{*}{$\begin{array}{l}\text { Paired ovarian } \\
\text { weight }(\mathrm{g})^{\mathrm{a}}\end{array}$} & \multicolumn{2}{|c|}{ Follicles } & \multirow[b]{2}{*}{$\begin{array}{c}\text { Serum } \\
\text { progesterone } \\
\left(\mathrm{ng} \mathrm{ml}^{-1}\right)\end{array}$} & \multirow[b]{2}{*}{$\begin{array}{c}\text { Daylength } \\
\text { (h:min) }\end{array}$} \\
\hline & & $\begin{array}{c}\text { Number } \\
\geq 20 \mathrm{~mm} \\
\text { in diameter }\end{array}$ & $\begin{array}{l}\text { Diameter of } \\
\text { largest }(\mathrm{mm})^{\mathrm{a}}\end{array}$ & & \\
\hline-1 & $73 \cdot 5 \pm 14 \cdot 6$ & $0.3 \pm 0.2^{s}$ & $13 \cdot 0 \pm 3 \cdot 0^{c}$ & $0.11 \pm 0.05$ & $10: 00$ \\
\hline 0 & $55.6+8.0$ & $\overline{0}^{\mathrm{c}}$ & $8.3+0.9^{c}$ & $0.08+0.01$ & $9: 59$ \\
\hline+1 & $61 \cdot 2 \pm 14 \cdot 3$ & $0^{c}$ & $10 \cdot 8 \pm 1 \cdot 4^{\mathrm{c}}$ & $0.23 \pm 0.12$ & $10: 01$ \\
\hline+2 & $61.4 \pm 7.6$ & $0 \cdot 1 \pm 0 \cdot 1^{\mathrm{c}}$ & $12 \cdot 8 \pm 1 \cdot 4^{\mathrm{c}}$ & $0.12 \pm 0.05$ & $10: 04$ \\
\hline+3 & $54 \cdot 3 \pm 7.0$ & $0.3 \pm 0.2^{\mathrm{c}}$ & $13 \cdot 1 \pm 2 \cdot 0^{\mathrm{c}}$ & $0.07 \pm 0.02$ & $10: 11$ \\
\hline+12 & $87.7 \pm 10.7$ & $3.3 \pm 0.7^{\mathrm{d}}$ & $25.1 \pm 1.9^{d}$ & $0.13 \pm 0.04$ & $11: 59$ \\
\hline
\end{tabular}

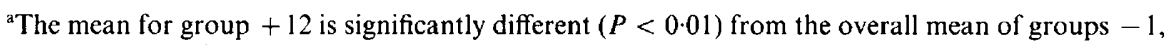
$0,+1,+2$ and +3 .

'Obtained from the tables of sunrise and sunset prepared by the Nautical Almanac Office, United States Naval Observatory.

${ }^{c, d}$ Within columns, means with different letters are significantly different $(P<0 \cdot 05)$.

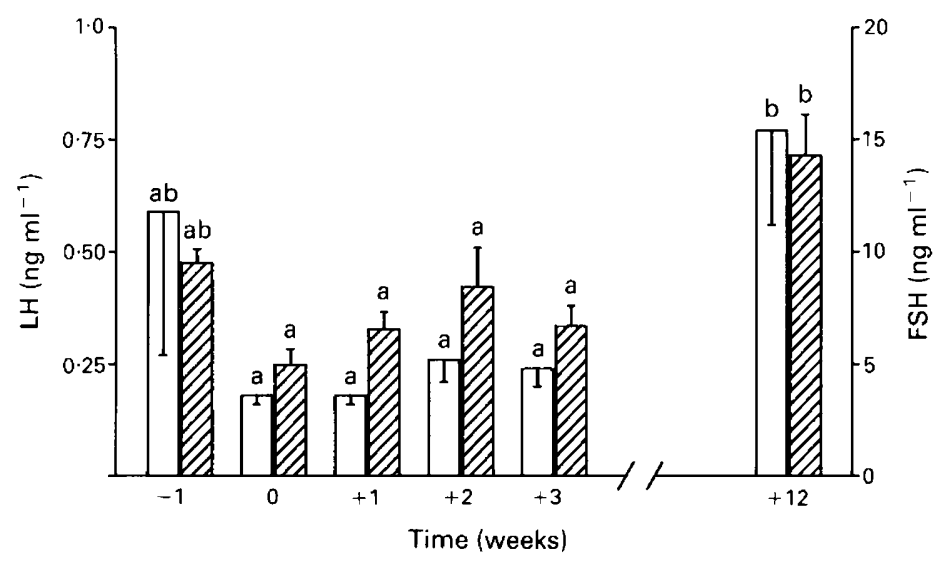

Fig. 1. Mean ( \pm SEM) concentrations of luteinizing hormone $(\square)$ and follicle-stimulating hormone $(\square)$ in serum of seasonally anoestrous mares in relation to the winter solstice (time $=0$ ). Samples were collected at the time of death. ${ }^{\mathrm{a}, \mathrm{b}}$ For each hormone, means without common letters are significantly different $(P<0.05)$.

Weight of the anterior pituitary was not affected by time relative to the winter solstice $(P>0 \cdot 1$; mean \pm SEM $=1.328 \pm 0.044 \mathrm{~g}$ ). Likewise, concentrations of LH and FSH in the pituitary gland did not vary over the entire experimental period; the mean ( \pm SEM) concentrations of LH and FSH were $0.268 \pm 0.036$ and $2.00 \pm 0.13 \mu \mathrm{g} \mathrm{mg}^{-1}$ pituitary, respectively $(n=56)$. No change was observed in content of GnRH in the body of the hypothalamus (mean \pm SEM $=9 \cdot 21 \pm 0.82 \mathrm{ng}$ $\mathrm{GnRH}$ per section). However, content of GnRH in anterior hypothalamic/preoptic suprachiasmatic area and median eminence regions changed significantly over the 13 week study $(P<0.001 ;$ Fig. 2$)$. The median eminence was not obtained for two mares in group +3 . GnRH concentrations in the median eminence were lowest in samples collected during the week preceding the winter solstice; by 
the day of the solstice mean concentrations of GnRH increased by about two times and at 1 week after the solstice the increase was $3 \cdot 5$-fold $(P<0.01)$ compared with group -1 . Content of $\mathrm{GnRH}$ in the median eminence remained high through week +2 ; by week +3 the mean decreased, although not significantly. Interestingly, by 12 weeks after the winter solstice GnRH in the median eminence had significantly decreased $(P<0.01)$ to concentrations that were not different from those in the week preceding the solstice. Content of $\mathrm{GnRH}$ in the anterior hypothalamic/preoptic suprachiasmatic area region showed a pattern reciprocal to that for the median eminence. Mean concentrations of GnRH in the anterior hypothalamic/preoptic suprachiasmatic area were lowest for group +1 and greatest for groups -1 and +12 . Samples from this region were not obtained for eight mares: five mares in group -1 , two mares in group 0 and one mare in group +3 .

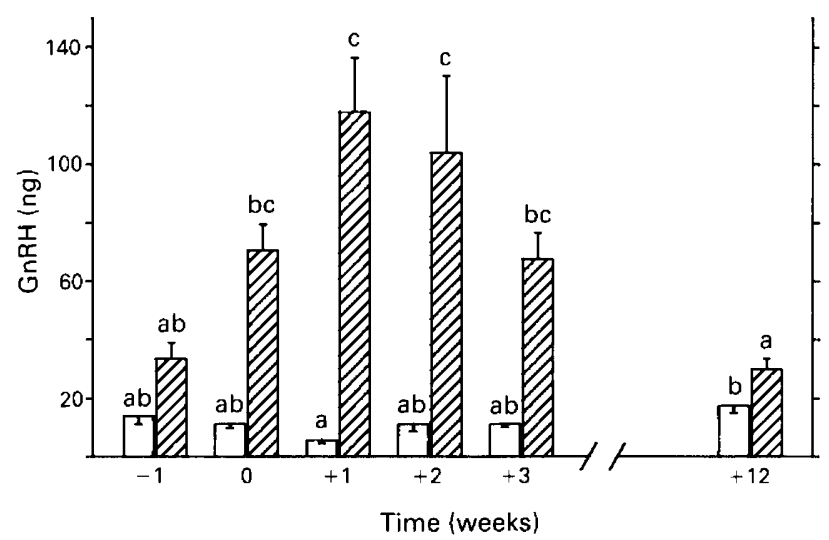

Fig. 2. Mean ( \pm SEM) content of gonadotrophin-releasing hormone in the anterior/preoptic $(\square)$ and median eminence $(\mathbb{Z})$ regions of the hypothalamus of seasonally anoestrous mares in relation to the winter solstice (time $=0$ ). The median eminence was not obtained for two mares in group +3 . The anterior/preoptic area was not obtained for eight mares: five mares in group -1 , two mares in group 0 and one mare in group $+3 .{ }^{\mathrm{a}-\mathrm{c}}$ Within each region, means without common letters are significantly different $(P<0.05)$.

\section{Discussion}

In this experiment, content of $\mathrm{GnRH}$ in the median eminence of nonpregnant horse mares was lowest I week before and 12 weeks after the winter solstice. Although not significantly increased on the day of the solstice, the mean concentration of GnRH for group 0 was two-fold higher than that of group-1. By 1 week after the solstice, the increase in mean content of GnRH in median eminence tissue had reached significance. At this time daylength was only $2 \mathrm{~min}$ longer than at the solstice (Table 1). It seems extremely unlikely that this small increase in daylength could be of any consequence in terms of stimulating synthesis of GnRH. The above sequence of events therefore appears compatible with a system that has become refractory to the preexisting 'short' photoperiodic environment. The phenomena of refractoriness to a prevailing photoperiod is well documented in seasonally breeding species (Turek et al., 1975; Bittman, 1978; Robinson \& Follett, 1982; Robinson et al., 1985). Reports from other laboratories support the possibility that refractoriness occurs during exposure to continued inhibitory photoperiods in both male and female equids. In mares, maintenance on short days, beginning from late fall, resulted in an interval to first ovulation not different from ambient controls (Kooistra \& Ginther, 1975; Palmer et al., 1982). Similarly, testicular size, sperm output and GnRH-stimulated LH release did not differ, at various collection times leading into the breeding season, for stallions maintained on ambient or short photoperiods (Clay et al., 1987a, b). The mechanism responsible for this postulated refractory condition is unknown. 
In mares, the hypothesis that an endogenous circannual rhythm underlies seasonal changes in reproductive activity has not been investigated. However, when the photic pathway from the eyes to the hypothalamus is interrupted, either by superior cervical ganglionectomy or pinealectomy, the interval to first ovulation in the first post-operative breeding season is not different from that of control (sham-operated) mares (Sharp et al., 1979; Grubaugh et al., 1982).

The increase in follicular activity and serum concentrations of LH and FSH seen in mares of group + 12 was expected, based upon previous results (Hart et al., 1984; Silvia et al., 1986; Silvia et al., 1987). It was anticipated that these animals would be well into the vernal transition, by which time concentrations of $\mathrm{GnRH}$ in the hypothalamus have recovered from the suppression associated with deep anoestrus.

Ability of endogenous (Alexander \& Irvine, 1987) as well as exogenous (Ginther \& Wentworth, 1974; Irvine et al., 1975; Evans \& Irvine, 1976; Oxender et al., 1977; Thompson et al., 1983; Hines et al., 1987; Silvia et al., 1987) GnRH to induce concurrent release of LH and FSH, from the equine pituitary gland, is strong support for its role as the primary hypothalamic stimulus of gonadotrophin secretion. Furthermore, active immunization of mares and geldings against GnRH produced significant reductions in circulating concentrations of LH and FSH (Garza et al., 1986; Safir et al., 1987; Rabb et al., 1990). In view of the aforementioned findings, low circulating concentrations of $\mathrm{LH}$ and FSH, observed during the 4 weeks associated with the winter solstice (groups $-1,0,+1,+2$ and +3 ), were probably a reflection of minimal secretion of $\mathrm{GnRH}$. This reasoning is further supported by the direct measurements of Sharp \& Grubaugh (1987). The signficant increase in gonadotrophin concentrations 12 weeks after the solstice is probably a result of renewed GnRH release. The coincidental, significant reduction in hypothalamic content of $\mathrm{GnRH}$ at this time also supports this result.

In agreement with previous work (Hart et al., 1984; Silvia et al., 1986), there was no change in pituitary concentrations of FSH over the 13 weeks of the experiment. The absence of seasonal variation in FSH stores may be important to assure systemic concentrations that can initiate and subsequently support follicular development as the transition into the breeding season begins. Concentrations of LH in the pituitary gland were also unchanged throughout this experiment. Failure to detect a significant increase in pituitary $\mathrm{LH}$ for group +12 , when concentrations of $\mathrm{LH}$ in serum were high, may indicate that these mares were not as far into the transition as anticipated. Studies of rat pituitary cell cultures have shown that increases (over incubation for $24 \mathrm{~h}$ ) in GnRHinduced LH release into the culture medium are not associated with corresponding changes in $\mathrm{LH}$ subunit messenger ribonucleic acids (Kim et al., 1988). In addition, acute treatment of pituitary cell preparations with GnRH did not increase incorporation of radiolabelled amino acids into LH that was immunoprecipitated from the medium (Liu et al., 1976). From these findings, it was concluded that the short-term effect of GnRH stimulation on the pituitary gland is increased secretion rather than increased synthesis of LH. Perhaps mares in group +12 were at the point where significant release of $\mathrm{GnRH}$ had just begun, resulting in the observed increase in systemic concentrations of LH without a corresponding increase in pituitary concentrations.

The experiment described here suffers from two inherent disadvantages. First, no background information (reproductive, nutritional or other) was available on the animals from which tissue samples were collected. However, given the economics of terminal studies in equine research, studies such as this, with sufficient numbers per group, can provide a sound foundation upon which to plan more controlled experiments. The second disadvantage of this experiment is the dependence upon content of various hormones in their respective tissues of origin. It must be emphasized that hormone content in a gland is a single, static measurement of a dynamic relationship between synthesis and release. Nevertheless, there is extensive knowledge about the effects of GnRH on synthesis and secretion of $\mathrm{LH}$ in other species, in addition to a well-documented gonadotrophin response to exogenous GnRH in mares. The simultaneous measurement of hypothalamic content of $\mathrm{GnRH}$, serum and pituitary concentrations of LH and FSH could provide sufficient information upon which to make cautious interpretations. 
In summary, the transition from reproductive anoestrus to the first ovulation of the breeding season is a continuum of physioendocrine changes that appear to begin very near or slightly in advance of the winter solstice. On the basis of these and previously published data, we suggest that a sequence of events occurs during the early phases of seasonal recrudescence in mares. First, GnRH and LH production and release are reduced during deep (i.e. $>90$ days before the first ovulation) seasonal anoestrus. Second, the first event in the process of recrudescence is an increase in hypothalamic GnRH production, which may occur as a result of refractoriness to the inhibitory photoperiod. Third, increased synthesis of $\mathrm{GnRH}$ is then followed by an increase in secretion that stimulates release of LH and FSH from the pituitary gland. Fourth, since FSH content of the pituitary remains high throughout the year, this renewed secretion of GnRH can produce concentrations of FSH in serum that are sufficient to initiate and sustain follicular development. In contrast, the low concentrations of $\mathrm{LH}$ present in the pituitary allow only slight increases in circulating concentrations of LH. Finally, as release of GnRH presumably continues, production of LH by the pituitary increases resulting in increased concentrations of $\mathrm{LH}$ in serum as mares proceed into the later phase of the transition into the breeding season.

It appears that there are two components involved in seasonal recrudescence of reproductive function in mares. First, a passive, photorefractory component which allows synthesis of GnRH to escape inhibitory influences of short daylengths and, second, an active, photostimulatory component (increasing daylength) which may serve to drive increases in synthesis and release of GnRH.

This work was presented in part at the Annual Meeting of the American Society of Animal Science, 1988. The experiment reported in this manuscript (No. 90-4-194) was funded by The Kentucky Equine Research Foundation and is published with the approval of the Director.

\section{References}

Alexander, S.L. \& Irvine, C.H.G. (1987) Secretion rates and short-term patterns of gonadotrophin-releasing hormone, $\mathrm{FSH}$ and $\mathrm{LH}$ throughout the periovulatory period in the mare. Journal of Endocrinology 114, 351-362.

Arthur, G.H. (1958) An analysis of the reproductive function of mares based on post-mortem examination. Veterinary Record 70, 682-686.

Bittman, E.L. (1978) Hamster refractoriness: the role in insensitivity of pineal target tissue. Science 202, $648-649$.

Burkhardt, J. (1947) Transition from anoestrus in the mare and the effects of artificial lighting. Journal of Agricultural Science 37, 64-68.

Clay, C.M., Squires, E.L., Amann, R.P. \& Nett, T.M. (I987a) Effects of daylength or artificial photoperiod on pituitary responsiveness to $\mathrm{GnRH}$ in stallions. Journal of Reproduction and Fertility Supplement 35, $657-658$.

Clay, C.M., Squires, E.L., Amann, R.P. \& Pickett, B.W. (1987b) Influences of season and artificial photoperiod on stallions: testicular size, seminal characteristics and sexual behavior. Journal of Animal Science 64, 517-525.

Evans, M.J. \& Irvine, C.H.G. (1976) Measurement of equine follicle stimulating hormone and luteinizing hormone: response of anestrous mares to gonadotropin releasing hormone. Biology of Reproduction 15, 477-484.

Fitzgerald, B.P. \& Mellbye, L.B. (1988) Effect of administration of an $\alpha_{2}$-adrenergic agonist, xylazine, on pulsatile gonadotrophin secretion in anoestrous horse mares. Journal of Reproduction and Fertility 84, 693-700.

Fitzgerald, B.P., Affleck, K.J., Barrows, S.P., Murdoch, W.L., Barker, K.B. \& Loy, R.G. (1987) Changes in LH pulse frequency and amplitude in intact mares during the transition into the breeding season. Journal of Reproduction and Fertility 79, 485-493.

Freedman, L.J., Garcia, M.C. \& Ginther, O.J. (1979) Influence of photoperiod and ovaries on seasonal reproductive activity in mares. Biology of Reproduction 20, $567-574$.

Garcia, M.C. \& Ginther, O.J. (1976) Effects of ovariectomy and season on plasma luteinizing hormone in mares. Endocrinology 98, 958-962.

Garza, F.J., Thompson, D.L., Jr, French, D.D., Wiest, J.J., St George, R.L., Ashley, K.B., Jones, L.S., Mitchell, P.S. \& McNeill, D.R. (1986) Active immunization of intact mares against gonadotropinreleasing hormone: differential effects on secretion of luteinizing hormone and follicle-stimulating hormone. Biology of Reproduction 35, 347-352.

Ginther, O.J. (1979) Reproductive Biology of the Mare. Basic and Applied Aspects. McNaughton and Gunn, Inc., Ann Arbor.

Ginther, O.J. \& Wentworth, B.C. (1974) Effect of a synthetic gonadotropin-releasing hormone in ponies. American Journal of Veterinary Research 35, 79-81.

Grubaugh, W., Sharp, D.C., Berglund, L.A., McDowell, K.J., Kilmer, D.M., Peck, L.S. \& Seamans, K.W. (1982) Effects of pinealectomy in pony mares. Journal of Reproduction and Fertility Supplement 32, 293-295. 
Hart, P.J., Squires, E.L., Imel, K.J. \& Nett, T.M. (1984) Seasonal variation in hypothalamic content of gonadotropin-releasing hormone $(\mathrm{GnRH})$ pituitary receptors for $\mathrm{GnRH}$, and pituitary content of luteinizing hormone and follicle-stimulating hormone in the mare. Biology of Reproduction 30, 1055-1062.

Hines, K.K., Fitzgerald, B.P. \& Loy, R.G. (1987) Effect of pulsatile gonadotrophin release on mean serum LH and FSH in peri-parturient mares. Journal of Reproduction and Fertility Supplement 35, 635-640.

Hines, K.K., Affleck, K.J., Barrows, S.P., Murdoch, W.L., Fitzgerald, B.P. \& Loy, R.G. (1991) Folliclestimulating hormone pulse amplitude decreases with onset of the breeding season in the mare. Biology of Reproduction 44, 516-521.

Hughes, J.P., Stabenfeldt, G.H. \& Evans, J.W. (1972) Clinical and endocrine aspects of the estrous cycle of the mare. Proceedings of the 18th Annual Convention of the American Association of Equine Practitioners, pp. I19-I51.

Irvine, D.S., Downey, B.R., Parker, W.G. \& Sullivan, J.J. (1975) Duration of oestrus and time of ovulation in mares treated with synthetic GnRH (AY-24,031). Journal of Reproduction and Fertility Supplement 23, 279-283.

Kim, W.H., Yuan, Q.X., Swerdloff, R.S. \& Bhasin, S. (1988) Regulation of alpha and luteinizing hormone beta subunit messenger ribonucleic acids during stimulatory and downregulatory phases of gonadotropinreleasing hormone action. Biology of Reproduction 39, $847-853$.

Kooistra, L.H. \& Ginther, O.J. (1975) Effect of photoperiod on reproductive activity and hair in mares. American Journal of Veterinary Research 36, 1413-1419.

Liu, T., Jackson, G.L. \& Gorski, J. (1976) Effects of synthetic gonadotropin-releasing hormone on incorporation of radioactive glucosamine and amino acids in luteinizing hormone and total protein by rat pituitaries in vitro. Endocrinology 98, 151-163.

Loy, R.G. (1968) Effects of artificial lighting regimes on reproductive patterns in mares. Proceedings of the I4th Annual Meeting of the American Association of Equine Practitioners, pp. 159-169.

Moss, G.E., Adams, T.E., Niswender, G.D. \& Nett, T.M. (1980) Effects of parturition and suckling on concentrations of pituitary gonadotropins, hypothalamic $\mathrm{GnRH}$ and pituitary responsiveness of $\mathrm{GnRH}$ in ewes. Journal of Animal Science 50, 496-502.

Nett, T.M. \& Adams, T.E. (1977) Further studies on the radioimmunoassay of gonadotropin-releasing hormone: effect of radioiodination, antiserum and unextracted serum on levels of immunoreactivity in serum. Endocrinology 101, 1135-1144.

Osborne, V.E. (1966) An analysis of the pattern of ovulation as it occurs in the annual reproductive cycle of the mare in Australia. Australian Veterinary Journal 42, 149-154.

Oxender, W.D., Noden, P.A. \& Pratt, M.C. (1977) Serum luteinizing hormone, estrus and ovulation in mares following treatment with prostaglandin F2 $\alpha$ and gonadotropin-releasing hormone. American Journal of Veterinary Research 38, 649-653.
Palmer, E., Driancourt, M.A. \& Ortavant, R. (1982) Photoperiodic stimulation of the mare during winter anoestrus. Journal of Reproduction and Fertility Supplement 32, 275-282.

Rabb, M.H., Thompson, D.L., Jr, Barry, B.E., Colborn, D.R., Hehnke, K.E. \& Garza, F.J. (1990) Effects of active immunization against $\mathrm{GnRH}$ on $\mathrm{LH}, \mathrm{FSH}$ and prolactin storage, secretion and response to secretagogues in pony geldings. Journal of Animal Science 68, 3322-3329.

Robinson, J.E. \& Follett, B.K. (1982) Photoperiodism in Japanese quail: the termination of seasonal breeding by photorefractoriness. Proceedings of the Royal Society of London-Biology 215, 95-116.

Robinson, J.E., Wayne, N.L. \& Karsch, F.J. (1985) Refractoriness to inhibitory daylength initiates the breeding season of the Suffolk ewe. Biology of Reproduction 32, 1024-1030.

Safir, J.M., Loy, R.G. \& Fitzgerald, B.P. (1987) Inhibition of ovulation in the mare by active immunization against LHRH. Journal of Reproduction and Fertility' Supplement 35, 229-237.

SAS Institute, Inc. (1985) SAS User's Guide: Version 5 Edition. SAS Institute, Inc., Cary.

Sharp, D.C. \& Grubaugh, W.R. (1987) Use of push-pull perfusion techniques in studies of gonadotrophinreleasing hormone secretion in mares. Journal of Reproduction and Fertility Supplement 35, 289-296.

Sharp, D.C., Vernon, M.W. \& Zavy, M.T. (1979) Alteration of seasonal reproductive patterns in mares following superior cervical ganglionectomy. Journal of Reproduction and Fertility Supplement 27, 87-93.

Silvia, P.J. \& Fitzgerald, B.P. (1991) Determinants of attenuated LH-release associated with the first ovulation of the equine breeding season. Domestic Animal Endocrinology 8, 255-264.

Silvia, P.J., Squires, E.L. \& Nett, T.M. (1986) Changes in the hypothalamic-hypophyseal axis of mares associated with seasonal reproductive recrudescence. Biology of Reproduction 35, 897-905.

Silvia, P.J., Squires, E.L. \& Nett, T.M. (1987) Pituitary responsiveness of mares challenged with $\mathrm{GnRH}$ at various stages of the transition into the breeding season. Journal of Animal Science 64, 790-796.

Thompson, D.L., Jr, Reville-Moroz, S.I., Derrick, O.J. \& Walker, M.P. (1983) Effects of testosterone, dihydrotestosterone and estradiol on gonadotropin release after gonadotropin-releasing hormone administration in cyclic mares. Biology of Reproduction 29, 970-976.

Tower, B.B., Sigel, M.B., Poland, R.E., VanderLann, W.P. \& Rubin, R.T. (1980) The Talc-Trichloroacetic Acid test for screening radioiodinated polypeptide hormones. In Methods in Enzymology, pp. 322-334. Eds H. Van Vunakis \& J. J. Langone. Academic Press, New York.

Turek, F.W., Elliott, J.A., Alvis, J.D. \& Menaker, M. (1975) Effect of prolonged exposure to nonstimulatory photoperiods on the activity of the neuroendocrinetesticular axis of golden hamsters. Biology of Reproduction 13, 475-481.

Received 1 August 1991 